\title{
Gondolatok az egyetemes és a magyar tudomány történetével kapcsolatban
}

\section{Berényi Dénes}

\begin{abstract}
Van, akinek furcsának tűnhet, hogy egy olyan kutató, aki nem a történelem területén dolgozik, a történelemmel kapcsolatban tesz megjegyzéseket, levon bizonyos következtetéseket. Úgy gondolom azonban, hogy a történelemnek, de különösen a tudománytörténetnek vannak olyan vonatkozásai, amelyek bármely tudományágban dolgozó kutató számára fontosak és elgondolkodtatók.
\end{abstract}

\section{A tudományokról általában}

Ha a tudományok feladatát általában akarjuk megfogalmazni, akkor röviden azt mondhatjuk, hogy céljuk a természet, az ember és a társadalom megismerése. Bármilyen tudományágról legyen is szó: társadalom-vagy természettudományról, eredményei, következtetései adatokon, méghozzá megbízható, minden kritikát kiálló adatokon nyugszanak. Természetesen mind az adatok természete, mind az adatgyüjtés módszere más és más, és nagymértékben különbözik az egyes tudományágak esetében. Például a történész a régi oklevelekből, krónikákból, különböző feljegyzésekből szerzi az adatokat, a szociológus kérdőíveket, interjúkat alkalmaz, míg a természettudományban az adatokat a megfigyelés, a kísérlet és a mérés szolgáltatja.

Hogy mennyire fontosak az adatok a humán- és a társadalomtudományokban is, arra vonatkozóan jellemző, hogy az Európai Unióban most készülnek felállítani egy ún. társadalomtudományi adatközpontot. A társadalom- és természettudományok között ezen kívül is - ti. hogy eredményeik adatokon alapulnak - számos átfedés van. Gondolhatunk itt például arra, hogy a történettudományban milyen fontos a régészet, a régészetben pedig egyre inkább tért hódítanak a természettudományos módszerek. Az 
is érdekes ebből a szempontból, hogy az EU ún. tudományos kerettervei, amelyek általában néhány évre vonatkoznak, és hamarosan a 7. ilyen veszi kezdetét, egészen a 6.-ig társadalomtudományi prioritásokat nem tartalmaztak. A 6. kerettervtől kezdve azonban van ilyen, mert világossá vált, hogy valamilyen új berendezés vagy technológia hiába nem ellenkezik a természet törvényeivel és hiába kivitelezhető műszakilag, gazdaságosnak is kell lennie, de mindezek ellenére lehet, hogy a társadalom mégsem fogadja el. A társadalomtudományoknak kell kideríteniük, hogy ha elfogadja a társadalom, miért fogadja el, és ha elutasítja, miért teszi ezt. További kutatási feladat annak kiderítése, hogy mit lehet és kell tenni ahhoz, hogy a társadalom mégis elfogadja a szóban forgó berendezést vagy technológiát.

Ismeretes, hogy a természettudomány intenzíven használja a matematikát is, sőt anélkül szinte elképzelhetetlen természettudományos kutatás. Van viszont a társadalomtudományok között is olyan, amelyik jelentős matematikai apparátussal dolgozik (közgazdaságtudomány), és nagyjából ezen az alapon különböztetik meg a „kemény” és a „lágy” társadalomtudományokat.

A továbbiak szempontjából érdemes itt megemlíteni, hogy a mai értelemben vett természettudomány a XVI. és XVII. század fordulóján, ill. a XVII. században született meg, és olyan nevek fémjelzik, mint Kopernikusz, Galilei, Kepler, Newton, de Harvey is.

\section{A tudománytörténet jelentősége}

Hogy a maga valójában tudjuk értékelni a tudományos eredményeket, ill. az azok elérésére tett erőfeszítéseket, nagyon fontos ismernünk azok megszületésének körülményeit. Azt például, hogy Galilei idejében semmi stopperórához hasonló nem állt rendelkezésre (egyáltalán használható óra kifejlődéséhez évszázadokra volt szükség), és kísérleteiben az időmérésre részben az érverést, részben a zenei taktusokat használta. De hiányoztak a tudományos fogalmak is, például meg kellett határozni, hogy mit jelent a gyorsaság és a sebesség, amelyek a mindennapi nyelvben alig különböztethetők meg, de mint fizikai fogalmak egészen más jelenséget jelölnek. Hasonlóan nem könnyủ a régi írások, oklevelek megfejtése, amikor részben az írásjelek is különböztek, részben pedig a mai helyesírástól teljesen eltérő 
szabályokat használtak, ha egyáltalán voltak ilyen szabályok. Mindezek tudatosításának különösen az oktatásban, de általában a tudományos szemlélet alakításában van kiemelkedő szerepe.

A ma emberét és a ma kutatóját a tudománytörténet tanítja meg arra, hogy megfelelő megértéssel értékelje a múlt tudományos eredményeit, és ne kapja el a ma tudományának gőgje - azt hívén, hogy mi már mindent jobban tudunk, és valahol az emberi tudás csúcsán vagyunk. Ez a bizonyos gőg sokszor megkísértette már az emberiséget és a tudomány művelőit. Például Anakszagórász (Kr. e. 500-428) sírján a következő feliratot olvashatjuk: „Itt nyugszik Anakszagórász, aki elérte az igazság legvégsó határát, megismerve a világegyetem felépítését." Galilei pedig arról panaszkodik, hogy korában vannak olyanok, akik az új gondolatokat nem tudják elfogadni és úgy viselkednek „... mintha minden megismerhetöt már ismernénk”. Végül érdemes itt idézni Gingyikint, a neves matematikust, aki szerint: „... hogy képesek legyünk érezni a nagy teljesítmények forradalmi jellegét, fontos része kultúránknak. A régen élt emberek iránt érzett gőg veszélyes emberi vonás."

\section{Az egyetemes tudomány története}

Az emberiség tudománytörténetét különböző szempontok szerint lehet áttekinteni. Az egyik ilyen szempont lehet a nagy nevek, illetve az általuk elért eredmények alapján történö áttekintés. Ilyen „vonulat” például Euklidész (a geometria "atyja”), Newton (a modern mechanika megteremtője), Lavoisier (a kémia Newtonja) vagy a legmodernebbeket tekintve: Planck, Einstein, Heisenberg. Hasonlóan például a történettudományban: Hérodotosz, Tacitus, Josephus Flavius, vagy nagyot ugorva: Toynbee, ill. az Annales-kör.

Egy másik áttekintési mód például a tudomány szervezeti keretei fejlődésének a nyomon követése. Az egyetemek szerepe nyilvánvaló a tudomány fejlődésében. Ezek a XI-XIII. században, tehát a középkorban alakultak ki és Bologna, Párizs, Oxford neve fémjelzi a kezdeteket.

A tudományos akadémiák majd félévezreddel később kerültek megalapításra, az elsők között a Royal Society (1662), de a világ legnevesebb tudományos akadémiái úgyszólván mind a XVII. század szülöttei.

Abban a században, amikor az akadémiák létrejöttek, kezdték kiadni az első tudományos folyóiratokat is Angliában és Franciaországban (pl. „Phylosophical Transactions" - 1665), míg korábban a tudományos eredmények 
levelezés és könyvek útján terjedtek. A legutóbbi évtizedekben egyre erőteljesebben elötérbe kerül az új közlési mód a digitális technika, a hálózatok felhasználásával.

A szervezett tudományos viták és megbeszélések, azaz a tudományos konferenciák leginkább a XIX. században szereztek polgárjogot világszerte.

Bár mint a világon mindennek, a tudományos kutatóintézeteknek is megtalálhatjuk az előzményeit, keletkezésük igazi időszaka azonban a XX. század, amikor tudományos akadémiákhoz kapcsolódóan vagy minisztériumi keretben megkezdték müködésüket az önálló tudományos kutatóintézetek.

A tudománytörténetről, a tudományos munka szervezeteiről és kereteiről szólva szót kell ejtenünk a tudományos kutatás egyik fő jellegzetességéröl, nevezetesen a nyilvánosságról. Arról van ugyanis szó, hogy a tudományos eredményt nyilvánosságra kell hozni. Ha ugyanis valaki csak saját gyönyörüségére vagy a fiókja számára végzi a kutatást, az még csak amatőr munka. Tudományossá akkor válik, ha az illető vagy illetők folyóiratokban, konferenciákon stb. nyilvánosságra hozzák az eredményt és megküzdenek azért, hogy a szóban forgó eredményt a tudományos közvélemény elfogadja, vagyis az beépüljön a tudomány épületébe. Ezt az erőfeszítést nem lehet megspórolni és nem lehet például arra spekulálni, hogy az eredményt a fiókomba teszem - mert magam sem vagyok meggyőződve annak helyességéről -, és majd, ha évek múlva valaki meggyőző adatokkal és érvelésekkel nyilvánosságra hozza a kérdéses eredményt, akkor előveszem a fiókomból elsőségemre apellálva. Nem szabad elfelejtenünk Werner Heisenberg figyelmeztetését: „A tudomány kísérleteken alapul, eredményei azonban beszélgetések során öltenek testet”. Vekerdi László viszont még élesebben fogalmaz: „Az újkori tudomány nagy eredményei szinte kivétel nélkül mind vitában születtek és izmosodtak meg ... A vitához ... az a küzdelem is hozzátartozik, amit az ellenkezőnek kell vívni véleménye elfogadtatásáért."

\section{A magyar tudomány története}

Természetesen ebben a fejezetben nem a magyar tudomány történetéröl lesz igazában szó, csak néhány megjegyzést teszek vele kapcsolatban.

Tény például, hogy a modern természettudomány megszületéséböl kimaradtunk. Magyar tudós nevét nem találjuk azok között, akiknek jelentős szerepe lett volna a modern tudomány megalapozásában. Nálunk ugyan- 
is hadszíntér volt ebben az időben, majd ezt követte az ország újjáépítése (XVIII. század) és ténylegesen csak a XIX. századtól kezdődött meg felzárkózásunk az európai tudományhoz. Érdemes ebből a szempontból például összehasonlítani a Royal Society alapításának évszámát (1662) és a Magyar Tudományos Akadémia alapításának évét (1825), vagy a már idézett első tudományos folyóirat megjelenését (1665) a megfelelő magyar folyóiratéval (Magyar Múzeum - 1788). Különben a XIX. század első felének magyar tudományosságát például Bolyai vagy Körösi Csoma Sándor neve fémjelzi, de az igazi felzárkózás a század második felében történt meg, amelyben döntő szerepe volt Eötvös Lorándnak. Ez az a kor, amikor egyre-másra alakultak hazánkban a tudományos egyesületek és jelentek meg az újabb és újabb tudományos folyóiratok. Elmondhatjuk, hogy minden későbbi történelmi vihar ellenére ettől kezdve a magyar tudományosság integráns része a világ tudományosságának, és hozzájárulásunk nem tekinthető elhanyagolhatónak (gondoljunk csak a magyar Nobel-díjasokra, de sok más az övékéhez hasonló eredményre).

Ezt a visszatekintést nem fejezhetjük be anélkül, hogy ne említenénk meg, hogy azért Magyarországon, éspedig mind északon, az ún. királyi Magyarországon, mind Erdélyben, azokban a bizonyos török időkben is történtek lépések a tudomány érdekében. Hadd említsük meg csak a Nagyszombati Egyetem alapítását (1635) vagy az ún. Báthori Egyetemet (1581).

\section{Az erdélyi tudományosság}

Nem kétséges, hogy sokan vannak nálam sokkal illetékesebbek, akik az erdélyi tudományos múltról beszélhetnek. Magam is szeretnék azonban szólni néhány olyan mérföldkőről, amelyik az erdélyi, de az egyetemes magyar tudománynak is jelentős eseménye, eredménye. A Báthori Egyetemet már emlitettem, de nem hagyhatjuk ki a Gyulafehérvári Főiskola müködését sem (Bethlen Gábor - 1622), majd a második magyar egyetem megalapítását Kolozsváron (1872).

Nem lehet eléggé kiemelni a jelentőségét az Erdélyi Magyar Nyelvmüvelö Társaságnak (1793), amely elsősorban Aranka György érdeme, és egyértelmủen a Magyar Tudományos Akadémia közvetlen elődjének tekinthető.

Mikó Imre viszont - Erdély Széchenyije - 1859-ben megalapította az Erdélyi Múzeum-Egyesületet, amely egyrészt valóban múzeum is, másrészt 
tudományos társaság, és hasonló szerepet töltött és tölt be Erdélyben, mint a Magyar Tudományos Akadémia az egyetemes magyar tudományosságban.

Nem lehet elhallgatni azt sem, hogy a már emlitett Bolyai (sőt a Bolyaiak) és Körösi Csoma Sándor is erdélyiek, de ugyanakkor természetesen az egyetemes magyar tudomány büszkeségei.

Befejezésül szeretném idézni Max von Laue Nobel-díjas fizikust: „Történelmet - teljes hủséggel is - igen eltérő szemszögből lehet írni; jogos minden nézőpont, ha abból a történetíró valami történetileg érdekeset tud teremteni."

Előadásomnak két nézőpontja volt. Az egyik: ahhoz, hogy helyesen tudjuk értékelni a múltban elért eredményeket, ahhoz létrejöttük történeti körülményeit is ismernünk kell. A másik: így értékelve a múlt tudományosságát helyesen tudjuk megítélni a jelen eredményeit, nem felejtve el, hogy fognak ezekre visszatekinteni ötven vagy száz év múlva.

Végül a tudományra és a tudománytörténetre, de valójában az egyes emberre és az egész emberiségre érvényes: aki a múltját nem becsüli, az a jövőjét sem érdemli. 